\title{
Peran Mediasi Self-Efficacy dan Peran Moderator Knowledge Sharing pada Empowering Leadership dan Perceived Organizational Support terhadap Employee Performance di UKM Batik HM. Sholeh Tuban
}

\author{
Ahmad Nuruddin \\ Ahmad Rizki Sridadi \\ Manajemen, Universitas Airlangga, Indonesia \\ Korespondensi penulis: ahmadnuruddin21@gmail.com
}

\begin{abstract}
This study uses objects in one of the Batik industries in Tuban, which is currently experiencing a fairly rapid growth in the increasingly competitive business environment. The focus of this research is on employee performance. This study aims to investigate the mechanism between empowering leadership and perceived organizational support for employee performance by using self efficacy as mediation and knowledge sharing as a moderator. This quantitative study is based on data collected using questionnaires distributed to 40 respondents of UKM Batik HM. Sholeh employees and using partial least square (PLS) technique for data analysis. In the results of the analysis using PLS, it was found that self-efficacy mediates the relationship of empowering leadership and perceived organizational support for employee performance. In addition, the role of knowledge sharing moderates or strengthens the relationship between self-efficacy and employee performance. Training of need analysis is necessary according to the more dynamic movement of the business world, especially in the batik industry. It is a rapidly growing industry, both from competitors and the technology used. So in this case, an innovation is also necessary to be able to compete effectively and to fill consumers' needs.
\end{abstract}

Keywords: Empowering leadership; Perceived organizational support; Self-efficacy; Knowledge sharing; Employee performance.

\begin{abstract}
Abstrak. Penelitian ini menggunakan obyek salah satu industri batik di Tuban yang mengalami pertumbuhan bisnis cukup pesat di dalam lingkungan bisnis berkembang semakin kompetitif. Fokus penelitian ini adalah kinerja karyawan. Penelitian ini bertujuan untuk mengkaji mekanisme antara empowering leadership dan perceived organizational support terhadap employee performance dengan menggunakan self-efficacy sebagai mediasi dan knowledge sharing sebagai moderator. Studi kuantitatif ini didasarkan pada data yang dikumpulkan menggunakan kuesioner yang diberikan kepada 40 responden karyawan UKM Batik HM. Sholeh dan menggunakan teknik partial least square (PLS) untuk analisis data. Hasil analisis data menggunakan PLS menemukan bahwa self-efficacy memediasi hubungan antara empowering leadership dan perceived organizational support terhadap employee performance. Selanjutnya, peran knowledge
\end{abstract}


sharing memoderasi atau memperkuat hubungan antara self-efficacy dan employee performance. Pelatihan analisis kebutuhan dibutuhkan karena semakin dinamisnya pergerakan dunia bisnis, terutama pada industri batik yang semakin berkembang pesat, baik dari pesaing maupun teknologi yang digunakan. Jadi, inovasi pun juga sangat diperlukan agar mampu bersaing secara efektif dan mampu memenuhi kebutuhan konsumen.

Kata Kunci: Pemberdayaan kepemimpinan; Persepsi dukungan organisasi; Kemampuan/kepercayaan diri; Berbagi pengetahuan; Kinerja karyawan.

\section{Article Info:}

Received: September 24, $2019 \quad$ Accepted: October 7, 2019 Available Online: December 1, 2019 DOI: http://dx.doi.org/10.30588/jmp.v9i1.522

\section{LATAR BELAKANG}

Dewasa ini, organisasi senantiasa bergerak pada lingkungan kompetitif yang ditandai adanya perubahan teknologi yang terjadi begitu cepat. Perubahan tersebut menciptakan iklim kompetitif yang semakin dapat dirasakan dengan semakin banyaknya pemain baru yang muncul di semua sektor industri maupun jasa. Pada gilirannya, kondisi tersebut menuntut organisasi mampu mengelola sumber daya manusia (SDM) secara efektif untuk mendapatkan keunggulan kompetitif. Sumber daya manusia yang memiliki pengetahuan dan kompetensi merupakan aset utama untuk membantu organisasi mempertahankan keunggulan kompetitif mereka (Ahmed et al., 2013). Dalam hal ini, employee performance atau kinerja karyawan merupakan faktor penting yang dipertimbangkan untuk membantu pencapaian tujuan organisasi. Performance berarti hasil perilaku atau tindakan yang sejalan dengan organisasi untuk mencapai tujuan yang ingin dicapai oleh karyawan dan sesuai dengan harapan organisasi (Mathis \& Jackson, 2000). Menurut Anitha (2014), employee performance merupakan hasil yang dicapai dan prestasi yang diraih di tempat kerja yang mengacu pada upaya untuk menjaga rencana kerja sambil mengincar hasilnya.

Terlepas dari hal-hal di atas, adanya keyakinan terhadap kemampuan pada setiap karyawan itu sendiri diperlukan untuk meningkatkan kinerjanya. Bandura (1997) mengemukakan bahwa self-efficacy memainkan peran penting dalam pencapaian kinerja yang berkaitan dengan tugas, yaitu mempengaruhi pilihan, upaya, dan kegigihan individu. Stajkovic (2006) menambahkan bahwa kepercayaan diri yang tinggi membuat orang lebih mungkin memulai tindakan, mengejarnya, dan mempertahankan kegigihan tersebut, karena mereka merasa yakin dapat menangani apa yang mereka inginkan atau perlu dilakukan untuk menenuhi tugas yang diberikan. Dengan demikian, ketekunan tinggi yang dikaitkan dengan self-efficacy pasti akan mengarah pada peningkatan kinerja dan produktifitas. Salah satu faktor kontekstual yang sangat ditekankan dalam organisasi dewasa ini adalah empowering leadership (Ahearne et al., 2005). Empowering leadership mengacu pada perilaku pemimpin yang berbagi kekuasaan dan mengalokasikan lebih banyak tanggung jawab dan otonomi kepada karyawan (Kirkman \& Rosen, 1999).

Peran pemimpin pada terjadinya self-efficacy karyawan sangatlah penting, sehingga empowering leadership berpengaruh terhadap self-efficacy. Penelitian Kim dan Beehr (2017) menyatakan adanya hubungan positif antara empowering leadership dan self-efficacy. Latham et al. (1994) juga menambahkan bahwa ketika para pemimpin 
yang memberdayakan (empowering leadership) akan mendorong karyawan untuk mengambil bagian dalam pengambilan keputusan terkait pekerjaan mereka dan meningkatkan keterlibatan mereka. Mereka memiliki peluang untuk memperluas pengetahuan dan saling belajar satu sama lain dengan bertukar informasi. Amundsen dan Martinsen (2014) menyatakan bahwa semua proses ini berkontribusi untuk menumbuhkan selfefficacy. Lebih jauh, para pemimpin yang memberdayakan harus terbiasa dengan kemampuan bawahan dan mendorong penggunaan kompetensi mereka, sehingga berkontribusi pada pengembangan self-efficacy karyawan. Pada penelitian ini, self-efficacy merupakan variabel mediasi yang memiliki peranan untuk memberikan kepercayaan dan tanggung jawab kepada karyawan yang dapat mempengaruhi employee performance. Saat ini, belum banyak penelitian yang menjelaskan terkait empowering leadership dan self-efficacy.

Selain empowering leadership yang dapat mendorong karyawan agar lebih meningkatkan kinerja mereka, perceived organizational support juga dapat mendorong karyawan untuk meningkatkan kinerja. Eisenberger et al. (1986) menjelaskan bahwa perceived organizational support atau dukungan organisasi yang dirasakan oleh karyawan merupakan suatu kepercayaan bahwa organisasi peduli terhadap kontribusi dan kesejahteraan karyawannya dan karyawan merasa aman dalam organisasi tersebut. Joo et al. (2015) menjelaskan bahwa karyawan akan terus bekerja di organisasi tempat mereka bekerja selama organisasi mereka tersebut peduli akan kesejahteraan mereka dan memberi mereka tugas operasional yang dianggap sesuai dengan kemampuan mereka. Peran knowledge sharing dalam proses pencapaian employee performance dapat meningkatkan efektivitas dalam pengambilan keputusan. Knowledge merupakan sumber daya organisasi yang memberikan keunggulan kompetitif berkelanjutan dalam ekonomi yang semakin kompetitif dan dinamis (Foss \& Pederson, 2002). Sebagai salah satu kegiatan yang berpusat pada knowledge, knowledge sharing merupakan sarana mendasar ketika karyawan dapat berkontribusi pada pengetahuan, inovasi, dan pada akhirnya pencapaian keunggulan kompetitif organisasi (Jackson et al., 2006). Knowledge sharing antarkaryawan memungkinkan organisasi untuk mengeksploitasi dan memanfaatkan sumber daya berbasis pengetahuan yang ada (Cabrera, E. \& Cabrera, A., 2005).

HM. Sholeh merupakan salah satu UKM (Usaha Kecil Menengah) sentra pengrajin batik di Kecamatan Kerek, Kabupaten Tuban, Provinsi Jawa Timur. Fokus dalam penelitian ini adalah employee performance yang ada di UKM Batik HM. Sholeh. Lebih tepatnya, employee performance pembatik sangat penting untuk meningkatkan keunggulan kompetitif. Berdasarkan hasil wawancara dengan penanggungjawab UKM HM. Sholeh, beberapa informasi dapat dikumpulkan, yaitu UKM yang bergerak di bidang industri batik saat ini sangat banyak yang menghasilkan produk serupa. Hal ini menyebabkan persaingan di antara mereka semakin ketat. Narasumber menuturkan bahwa penurunan pesanan terjadi pada beberapa tahun terakhir. Namun, penurunannya masih belum signifikan. Hal itu pula yang menyebabkan penurunan omset pada beberapa tahun terakhir. Dengan fenomena tersebut, kinerja atau output yang dihasilkan oleh para karyawannya juga cenderung menurun. Apabila dilihat pada kondisi lapangan, masih terdapat tingkat kesalahan dalam pembuatan batik yg dilakukan oleh karyawan UKM Batik HM. Sholeh. Hal tersebut akan berpengaruh terhadap kualitas hasil yang nantinya dapat mempengaruhi selera konsumen. Oleh karena itu, kecakapan dan kemampuan yang mumpuni dari masing-masing karyawan harus dikembangkan dan diperhatikan. 
Tinggi rendahnya volume batik yang diproduksi sangat dipengaruhi oleh kinerja karyawan UKM Batik HM. Sholeh. Semakin baik kinerja karyawan, maka produksi batik akan semakin meningkat.

Berdasarkan uraian di atas, penurunan omset terjadi pada tahun 2015 hingga 2017. Penurunan cukup signifikan terjadi pada tahun 2016 senilai Rp1,54 miliar dan pada tahun sebelumnya sebesar Rp1,87 miliar. Hal tersebut disebabkan semakin banyaknya pemain baru yang muncul di industri batik dan menyebabkan terjadinya penurunan pesanan, output yang dihasilkan pun juga menurun. Hal itu pula yang menyebabkan menurunnya kinerja karyawan, karena semakin berkurangnya output yang dihasilkan. Kendala lain yang terjadi adalah pengusaha belum mampu menyelesaikan pesanan sesuai dengan waktu yang ditentukan di awal ketika pesanan sedang ramai dan konsumen meminta segera diselesaikan. Namun, solusi lain adalah para karyawan mengerjakan terlebih dulu pesanan yang lebih urgent atau segera diambil oleh konsumen atau pemesannya.

Untuk meningkatkan kinerja karyawan perlu adanya dukungan atau dorongan dari organisasi yang senantiasa menghargai kontribusi karyawan, menyediakan kondisi kerja yang baik, dan memberikan kesejahteraan bagi mereka (Rhoades \& Eisenberger, 2002). Selain dukungan dari organisasi, self-efficacy pada karyawan juga memainkan peran penting yang berpengaruh dalam menentukan pilihan individu, tingkat upaya, dan ketekunan (Chen, G. et al. 2004). Pada akhirnya, karyawan akan melaksanakan tindakan dengan menekankan kemampuan maupun ketrampilan yang dimilikinya untuk mencapai kinerja yang maksimal. Sesuai dengan fenomena dan penjelasan di atas, maka penelitian bertujuan melakukan pengujian peran mediasi self-efficacy dan peran moderator knowledge sharing pada hubungan empowering leadership dan perceived organizational support terhadap employee performance.

Berdasarkan uraian latar belakang, maka permasalahan yang akan ditelaah dalam penelitian ini adalah: (a) Apakah empowering leadership berpengaruh terhadap employyee performance? (b) Apakah perceived organizational support berpengaruh terhadap employee performance? (c) Apakah self-efficacy berpengaruh terhadap employee performance? (d) Apakah self-efficacy memediasi pengaruh antara empowering leadership terhadap employee performance? (e) Apakah self-efficacy memediasi pengaruh antara perceived organizational support terhadap employee performance? (f) Apakah knowledge sharing memoderatori pengaruh self-efficacy terhadap employee performance?

Berdasarkan permasalahan tersebut, maka tujuan yang ingin dicapai dalam penelitian ini adalah: (a) Untuk menguji dan menganalisis pengaruh empowering leadership terhadap employee performance; (b) Untuk menguji dan menganalisis pengaruh perceived organizational support terhadap employee performance; (c) Untuk menguji dan menganalisis pengaruh self-efficacy terhadap employee performance; (d) Untuk menguji dan menganalisis peran mediasi self-efficacy pada pengaruh empowering leadership terhadap employee performance; (e) Untuk menguji dan menganalisis peran mediasi self-efficacy pada pengaruh perceived organizational support terhadap employee performance; (f) Untuk menguji dan menganalisis peran moderator knowledge sharing pada pengaruh self-efficacy terhadap employee performance. 


\section{KAJIAN TEORITIS}

\section{Empowering Leadership}

Empowering leadership merupakan suatu proses berbagi kekuasaan, dan mengalokasikan otonomi dan tanggung jawab kepada pengikut, tim, atau kolektif melalui serangkaian perilaku pemimpin khusus bagi karyawan untuk meningkatkan motivasi internal dan mencapai keberhasilan kerja (Amundsen et al., 2014). Yukl (2006) mendefinisikan leadership sebagai proses mempengaruhi orang lain untuk memahami dan melaksanakan apa yang perlu dilakukan dan bagaimana melakukannya, serta proses memfasilitasi upaya individu dan kolektif untuk mencapai tujuan bersama. Empowering leadership telah dipelajari dari dua perspektif berbeda. Pertama, berfokus pada tindakan pemimpin, khususnya berbagi kekuasaan atau memberikan lebih banyak tanggung jawab dan otonomi kepada karyawan (Kirkman \& Rosen, 1999). Kedua, berfokus pada tanggapan karyawan terhadap pemberdayaan, khususnya motivasi karyawan untuk pemberdayaan (Conger \& Kanungo, 1988).

\section{Perceived Organizational Support}

Perceived Organizational Support (POS) merupakan dukungan organisasi yang mengacu pada persepsi karyawan mengenai sejauh mana organisasi menghargai dan mendukung kontribusi mereka, memberikan kondisi kerja yang baik, dan peduli terhadap kesejahteraan mereka, maka semakin tinggi dukungan organisasi yang dirasakan karyawan akan semakin rendah tingkat absensinya (Rhoades \& Eisenberger, 2002). Di sisi lain, Pack (2005) menjelaskan POS merupakan persepsi karyawan tentang sejauh mana organisasi memberikan dukungan pada karyawan dan sejauh mana kesiapan organisasi memberikan bantuan saat dibutuhkan. Karyawan yang mempersepsikan dukungan organisasi yang lebih tinggi akan menemukan pekerjaan mereka lebih menyenangkan, berada dalam suasana hati yang lebih baik dalam melakukan tugas-tugas mereka, dan mengalami lebih sedikit gejala ketegangan seperti kecemasan (Rhoades \& Eisenberger, 2002).

\section{Self-efficacy}

Self-efficacy merupakan konsep untuk menjelaskan perilaku manusia yang memainkan peran penting dalam menentukan pilihan individu, tingkat upaya, dan ketekunan (Chen, G. et al., 2004). Bandura (2006) menjelaskan bahwa karyawan dengan keyakinan self-efficacy cenderung lebih trampil, menunjukkan kegigihan, mampu menyelesaikan pekerjaan, intensitas tinggi pendekatan mereka terhadap peran pekerjaan, dan mencari tujuan yang lebih menantang. Cavazotte, et al. (2013) menambahkan bahwa self-efficacy dengan keyakinan tinggi yang dimiliki seseorang dalam kapasitasnya di bidang tertentu dapat dianggap sebagai salah satu faktor utama untuk mendorong pencapaian tujuan.

\section{Employee Performance}

Performance atau kinerja merupakan faktor multikarakter utama yang dimaksudkan untuk mencapai hasil yang memiliki hubungan erat dengan tujuan organisasi yang direncanakan (Mwita, 2000). Performance merupakan pencapaian hasil yang dikarakteristikkan dengan keahlian seseorang atas dasar tujuan yang telah ditetapkan sebelumnya (Hori et al., 2005). Employee performance pada dasarnya merupakan hasil yang dicapai dan prestasi yang dibuat di tempat kerja dan mengacu pada upaya untuk menjaga rencana sambil mengincar hasilnya (Anitha, 2014). Cardy (2004) menam- 
bahkan bahwa employee performance sangat bergantung pada kebijakan, praktik, dan fitur disain organisasi.

\section{Knowledge Sharing}

Knowledge sharing merupakan kegiatan berbagi ide atau informasi melalui komunikasi dan interaksi antara individu dan orang yang diinginkan (Mitttal \& Dhar, 2015). Hasil dari berbagi pengetahuan tergantung pada kualitas dan kuantitas komunikasi antara sumber daya manusia, kesiapan untuk menggunakan pengetahuan, dan kompetensi individu (Liao, 2006). Lin (2007) mendefinisikan knowledge sharing sebagai budaya interaksi sosial yang melibatkan pertukaran pengetahuan, pengalaman, dan ketrampilan karyawan melalui seluruh departemen atau organisasi. Syed-Ikhsan dan Rowland (2004) menjelaskan bahwa knowledge sharing merupakan sesuatu hal penting bagi perusahaan untuk meraih kesuksesan yang mengarah pada penyebaran pengetahuan lebih cepat dan berbagi pengetahuan untuk sebagian organisasi agar dapat memberikan keuntungan lebih besar di masa mendatang.

\section{Pengembangan Hipotesis}

\section{Pengaruh Empowering Leadership terhadap Employee Performance}

Amundsen dan Martinsen (2014) menjelaskan bahwa empowering leadership merupakan suatu proses berbagi kekuasaan dan mengalokasikan otonomi dan tanggung jawab kepada pengikut, tim, atau kolektif melalui serangkaian perilaku pemimpin, khususnya bagi karyawan untuk meningkatkan motivasi internal dan mencapai keberhasilan kerja, sedangkan Liu et al (2003) mendefinisikan empowering leadership sebagai gaya kepemimpinan yang menargetkan pengikut untuk mengembangkan kontrol diri mereka sendiri, yaitu karyawan didorong untuk berpartisipasi dalam pengambilan keputusan dan diarahkan untuk berinovasi sendiri. Saat individu merasa bahwa dirinya diberikan kepercayaan, berpartisipasi dalam pengambilan keputusan, serta mendapatkan dukungan dan dorongan, maka mereka akan merasa lebih giat dalam bekerja untuk mencapai kinerja, sehingga tercapailah employee performance. Hal ini dukung oleh Lee, S. et al. (2017) yang menyatakan bahwa empowering leadership berpengaruh signifikan terhadap kinerja karyawan. Penelitian yang dilakukan oleh Tung dan Chang (2011) juga menjelaskan bahwa empowering leadership memiliki pengaruh positif dan signifikan terhadap employee performance. Dengan demikian, hipotesis kesatu (H1) dalam penelitian ini dinyatakan sebagai berikut:

\section{H1: Empowering leadership berpengaruh positif dan signifikan terhadap emplo- yee performance.}

\section{Pengaruh Perceived Organizational Support terhadap Employee Performance}

Dukungan organisasional dipengaruhi oleh interaksi seseorang dengan organisasi ketika organisasi tersebut memberikan pujian, dukungan, dan persetujuan. Rhoades et al. (2001) menyatakan bahwa perceived organizational support dipengaruhi oleh frekuensi, usaha pemberian pujian, penghargaan, dan rewards lainnya. Karyawan yang menerima dukungan organisasi tingkat tinggi juga cenderung lebih menunjukkan suasana hati yang positif, sehingga pada gilirannya dukungan tersebut dapat memfasilitasi terwujudnya employee performance. Pernyataan tersebut didukung oleh penelitian yang dilakukan oleh Chen, Z. et al (2009) yang menyatakan adanya pengaruh positif 
perceived organizational support terhadap performance. Cullen et al. (2014) juga menjelaskan adanya pengaruh positif dan signifikan perceived organizational support terhadap employee performance. Demikian pula, penelitian yang dilakukan oleh Byrne dan Hochwarter (2008) menyatakan perceived organizational support berpengaruh positif dan signifikan terhadap employee performance. Untuk itu, hipotesis kedua (H2) dalam penelitian ini dinyatakan sebagai berikut:

\section{H2: Perceived organizational support berpengaruh positif dan signifikan terhadap employee performance.}

\section{Pengaruh Self-efficacy terhadap Employee Performance}

Self-efficacy merupakan konsep penting untuk menjelaskan perilaku manusia, ketika beberapa penelitian mengungkapkan bahwa konsep itu memainkan peran yang berpengaruh dalam menentukan pilihan individu, tingkat upaya, dan ketekunan (Chen, G. et al., 2004). Stajkovic (2006) mengemukakan bahwa karyawan yang memiliki selfefficacy yang tinggi lebih mungkin untuk memulai tindakan, mengejarnya, dan mempertahankan kegigihan, karena mereka merasa yakin dapat menangani apa yang mereka inginkan atau perlu dilakukan. Beberapa hasil penelitian sebelumnya menjelaskan bahwa self-efficacy berpengaruh terhadap employee performance. Seperti penelitian yang dilakukan oleh Tims et al. (2014) yang menunjukkan bahwa terdapat pengaruh positif dan signifikan antara self-efficacy terhadap employee performance. Penelitian lain yang dilakukan oleh Su et al. (2016) menunjukkan pula pengaruh positif selfefficacy dan employee performance. Dengan demikian, hipotesis ketiga $(\mathrm{H} 3)$ dalam penelitian ini dinyatakan sebagai berikut:

\section{H3: Self-efficacy berpengaruh positif dan signifikan terhadap Employee Perfor- mance.}

\section{Peran mediasi Self-efficacy terhadap Empowering Leadership dan Employee Performance}

Ahearne et al. (2005) menjelaskan konseptualisasi empowering leadership adalah melibatkan peningkatan makna kerja, mendorong partisipasi dalam pengambilan keputusan, mengungkapkan keyakinan dalam berkinerja, dan memberikan otonomi dalam hambatan birokrasi. Latham et al. (1994) menjelaskan bahwa ketika para pemimpin yang memberdayakan mendorong karyawan untuk mengambil bagian dalam pengambilan keputusan terkait pekerjaan mereka dan meningkatkan keterlibatan mereka, maka mereka memiliki peluang untuk memperluas pengetahuan dan saling belajar satu sama lain dengan bertukar informasi. Amundsen \& Martinsen (2014) juga menambahkan bahwa semua proses ini berkontribusi untuk mendorong self-efficacy. Lebih jauh, para pemimpin yang memberdayakan harus terbiasa dengan kemampuan bawahan mereka dan mendorong penggunaan kompetensi mereka, yang pada akhirnya dapat berkontribusi pada pengembangan self-efficacy karyawan. Menurut Bandura (1997), selfefficacy dapat mempengaruhi daya tarik dan inisiatif yang berkaitan dengan tugas yang diberikan. Saat individu merasa bahwa dirinya mampu dan yakin dapat menghasilkan suatu hasil maksimal yang sesuai dengan kemampuan yang dimilikinya, maka individu tersebut akan merasa lebih giat dalam berkinerja, berpikir, maupun bertindak kreatif, sehingga employee performance akan tercapai. Hasil penelitian Kim dan Beehr (2017) menjelaskan bahwa empowering leadership memiliki pengaruh positif terhadap selfefficacy. Selanjutnya, penelitian Tims et al. (2014) menunjukkan adanya pengaruh posi- 
tif dan signifikan antara self-efficacy terhadap employee performance. Dengan demikian, hipotesis keempat $(\mathrm{H} 4)$ dalam penelitian ini dinyatakan sebagai berikut:

\section{H4: Self-efficacy memediasi pengaruh positif dan signifikan Empowering Leader- ship terhadap Employee Performance.}

\section{Peran mediasi Self-efficacy terhadap Perceived Organizational Support dan Employee Performance}

Karyawan yang mempersepsikan tingginya dukungan organisasi akan menemukan pekerjaan mereka terasa lebih menyenangkan, berada dalam suasana hati yang lebih baik dalam melakukan tugas-tugas mereka, dan mengalami lebih sedikit gejala ketegangan seperti kecemasan (Rhoades \& Eisenberger, 2002). Selanjutnya, self-efficacy mengacu pada kemampuan yang dirasakan seseorang untuk melaksanakan tindakan dengan menekankan ketrampilan yang dimiliki untuk mencapai misi yang diberikan (Bandura, 1997). Self-efficacy merupakan konsep penting untuk menjelaskan perilaku manusia ketika dalam memainkan peran yang berpengaruh untuk menentukan pilihan individu, tingkat upaya, dan ketekunan (Chen, G. et al., 2004). Saat individu merasa bahwa dirinya mampu dan yakin dapat menghasilkan suatu hasil yang maksimal sesuai dengan kemampuan yang dimilikinya, maka ia akan merasa lebih giat meraih kinerja, sehingga employee performance dapat tercapai. Hasil penelitian Su et al. (2016) menunjukkan adanya pengaruh positif self-efficacy terhadap employee performance. Selain itu, Diliello et al. (2011) juga menjelaskan bahwa semakin besar tingkat dukungan organisasi yang dirasakan karyawan, maka semakin besar pula self-efficacy pada karyawan. Hal ini didukung penelitian Thakur \& Kumar (2015) yang menjelaskan bahwa perceived organizational support memiliki pengaruh positif terhadap self-efficacy. Untuk itu, hipotesis kelima (H5) dalam penelitian ini dinyatakan sebagai berikut:

\section{H5: Self-efficacy memediasi pengaruh positif dan signifikan Perceived Organiza- tional Support terhadap Employee Performance.}

\section{Peran Moderasi Knowledge Sharing terhadap Self-efficacy dan Employee Per- formance}

Knowledge sharing merupakan kegiatan berbagi ide atau informasi melalui komunikasi dan interaksi antara individu dan orang yang diinginkan (Mittal \& Dhar, 2015). Hasil dari tindakan berbagi pengetahuan tergantung pada kualitas dan kuantitas komunikasi antara sumber daya manusia, kesiapan untuk menggunakan pengetahuan, dan kompetensi individu (Liao, 2006). Syed-Ikhsan \& Rowland (2004) menyatakan bahwa knowledge sharing merupakan sesuatu hal penting bagi perusahaan untuk meraih kesuksesan yang mengarah pada penyebaran pengetahuan lebih cepat dan berbagi pengetahuan untuk sebagian organisasi dapat memberikan keuntungan lebih besar di masa mendatang. Hanninen (2007) menemukan bahwa karyawan yang berpengetahuan mengungkapkan kepercayaan diri yang lebih besar, (yaitu self-efficacy) daripada rekan kerja mereka dalam meraih tujuan yang menantang. Karyawan yang memperoleh pengetahuan melalui tindakan berbagi, mereka akan menjadi lebih percaya diri, dan memiliki kapasitas daya serap yang baik dalam berkinerja, yang pada akhirnya akan meningkatkan employee performance. Pada penelitian yang dilakukan Lee, E. et al. (2007) juga menjelaskan bahwa terdapat pengaruh positif antara knowlegde sharing dan self-efficacy. Selanjutnya, penelitian lain yang dilakukan oleh Tims et al. (2014) menunjukkan bahwa terdapat pengaruh positif dan signifikan antara self-efficacy terhadap 
employee performance. Untuk itu, hipotesis keenam (H6) dalam penelitian ini dinyatakan sebagai berikut:

\section{H6: Knowledge sharing memoderasi pengaruh positif dan signifikan Self-efficacy terhadap Employee Performance.}

\section{Kerangka Konseptual}

Gambar 1 berikut ini merupakan kerangka konseptual yang digunakan dalam penelitian ini untuk menggambarkan keterkaitan antarvariabel, yaitu pengaruh empowering leadership dan perceived organizational support terhadap employee performance yang dimediasi oleh self-efficacy dan moderasi knowledge sharing pada pengaruh self-efficacy terhadap employee performance.

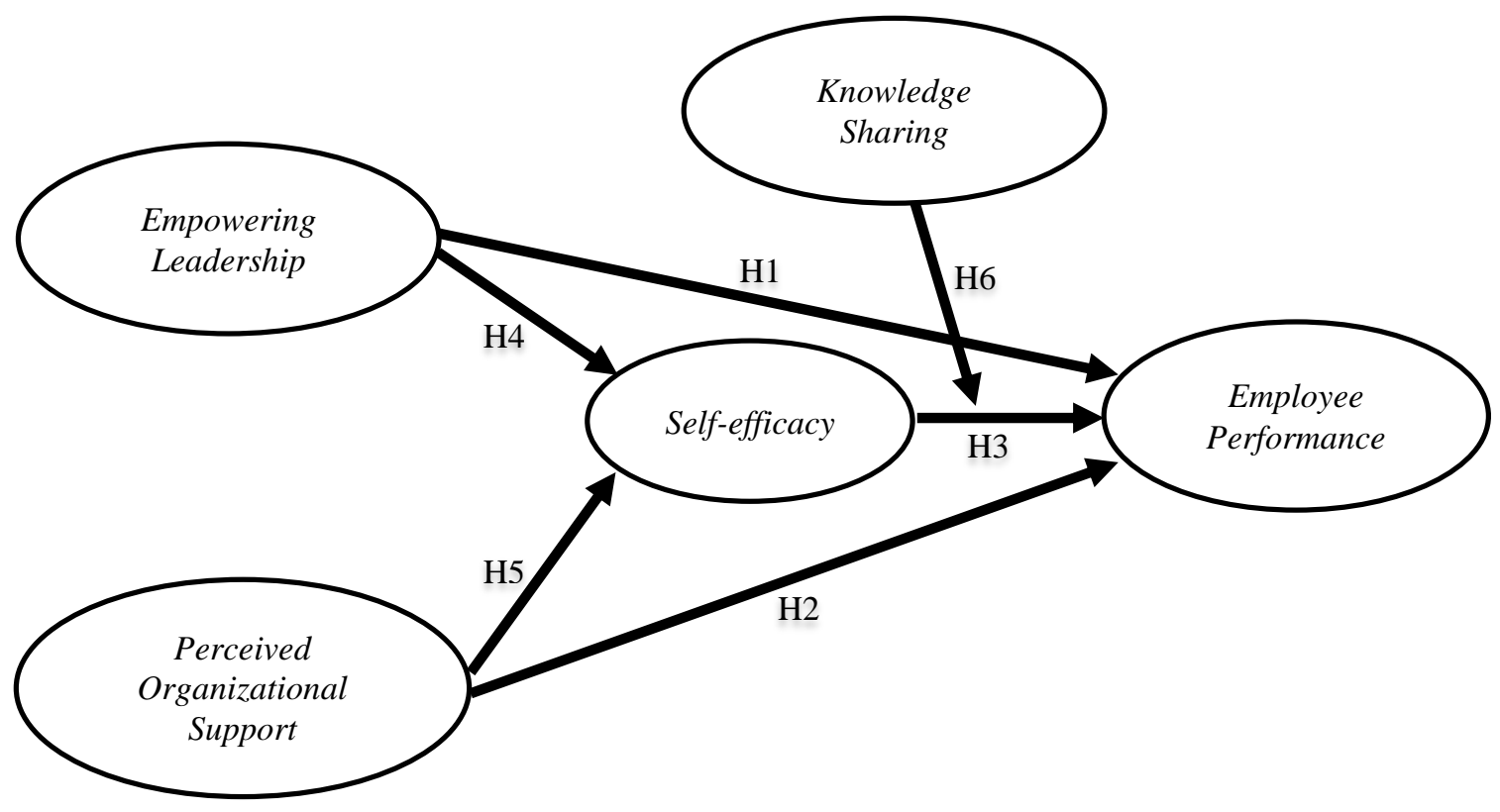

Gambar 1. Model Penelitian

\section{METODE PENELITIAN}

Penelitian ini dilakukan pada salah satu UKM di Kabupaten Tuban, Jawa Timur, sedangkan fokus penelitian ini adalah kinerja karyawan pada UKM Batik HM. Sholeh. Pendekatan yang digunakan dalam penelitian ini adalah pendekatan kuantitatif. Teknik pengumpulan data menggunakan kuesioner dengan skala Likert 1-5. Populasi dalam penelitian ini adalah 60 orang pembatik. Peneliti menggunakan pursposive sampling dengan menetapkan 40 responden yang dijadikan sampel berdasarkan kriteria bahwa sampel adalah karyawan yang bekerja sebagai pembatik. Responden juga memberikan tanggapan terkait pertanyaan tentang karakteristik demografi meliputi usia, jenis kelamin, pendidikan terakhir, dan lama bekerja. Teknik analisis data dalam penelitian ini menggunakan Partial Least Square (PLS) yang merupakan metode analisis yang powerfull karena tidak didasarkan pada banyaknya asumsi, serta data tidak harus berdistribusi normal dan sampel tidak harus berjumlah besar (Ghozali, 2011). 


\section{Skala dan Pengukuran}

Variabel dalam penelitian ini adalah empowering leadership, perceived organizational support, self-efficacy, employee performance, dan knowledge sharing. Variabel empowering leadership diukur menggunakan pengukuran yang telah dilakukan oleh Ahearne et al. (2005) yang berjumlah tiga butir. Perceived organizational support diukur atas dasar pengukuran yang dilakukan Rhoades dan Eisenberger (2002) terdiri atas tiga butir. Self-efficacy diukur menggunakan pengukuran dari Bandura (2006) yang berisi tiga butir. Employee performance diukur menggunakan pengukuran oleh McNeese-Smith (1996) yang terdiri atas tiga butir. Knowledge sharing diukur berdasarkan pengukuran Lin (2007) yang berisi tiga butir. Evaluasi dalam discriminant validity dilakukan dengan menyimpulkan hasil cross-loading pada setiap indikator pernyataan yang menyusun variabel. Sementara itu, evaluasi composite reliability dapat memenuhi apabila nilainya lebih dari 0,7 serta memiliki nilai Cronbach's alpha lebih besar dari 0,6 (Jogiyanto, 2011). Pilihan jawaban pada penelitian ini menggunakan skala Likert (Tabel 1) berikut ini.

Tabel 1. Indeks Skala Likert

\begin{tabular}{ccc}
\hline Alternatif Jawaban & Keterangan & Skor \\
\hline STS & Sangat Tidak Setuju & 1 \\
TS & Tidak Setuju & 2 \\
CS & Cukup Setuju & 3 \\
S & Setuju & 4 \\
SS & Sangat Setuju & 5 \\
\hline
\end{tabular}

\section{HASIL DAN PEMBAHASAN}

Hasil uji statistik menunjukkan nilai $\mathrm{R}^{2}$ pada variabel employee performance sebesar 0,714 artinya bahwa persentase besarnya keragaman persepsi karyawan pada employee performance dapat dijelaskan oleh variabel empowering leadership, perceived organizational support, self-efficacy dengan moderasi knowledge sharing sebesar $71,4 \%$, sedangkan $28,6 \%$ sisanya dijelaskan oleh variabel di luar model penelitian yang dianalisis. Selanjutnya, nilai $\mathrm{R}^{2}$ pada variabel self-efficacy sebesar 0,536 artinya persentase keragaman persepsi karyawan UKM Batik HM. Sholeh pada variabel self-efficacy dapat dijelaskan oleh variabel empowering leadership dan perceived organizational support sebesar 53,6\%, sedangkan 46,4\% sisanya dijelaskan oleh variabel di luar model penelitian.

\section{Uji Hipotesis}

Hasil uji hipotesis pada Tabel 2 menunjukkan bahwa nilai t-statistics pengaruh empowering leadership terhadap employee performance sebesar 2,003 (>1,64) dan nilai original sampel sebesar 0,264 (positif), sehingga H1 dapat diterima. Artinya, ketika karyawan merasakan empowering leadership dalam organisasinya semakin tinggi, maka hal itu akan meningkatkan employee performance. Hasil penelitian ini didukung oleh penelitian Tung dan Chang (2011).

Hasil uji hipotesis kedua menunjukkan bahwa nilai t-statistics pengaruh perceived organizational support terhadap employee performance sebesar $1,145(<1,64)$ dan nilai 
original sampel sebesar 0,116 (positif), sehingga $\mathrm{H} 2$ ditolak. Artinya, ketika karyawan mempersepsikan organizational support di dalam organisasinya kecil, maka kemungkinannya dapat berpengaruh pada employee performance. Hasil penelitian ini didukung oleh penelitian Fatima et al. (2015) yang menyatakan bahwa perceived organizational support berpengaruh tidak signifikan terhadap employee performance.

Tabel 2. Hasil Pengujian Hipotesis

\begin{tabular}{|c|c|c|c|c|}
\hline Hubungan Antarvariabel & $\begin{array}{c}\text { t-Statistics } \\
(>1,64)\end{array}$ & Keterangan & $\begin{array}{l}\text { Original } \\
\text { Sampel }\end{array}$ & Keterangan \\
\hline $\begin{array}{l}\text { - Empowering Leadership } \rightarrow \\
\text { Employee Performance }\end{array}$ & 2,003 & Signifikan & 0,264 & Positif \\
\hline $\begin{array}{l}\text { - Perceived Organizational } \\
\text { Support } \rightarrow \text { Employee } \\
\text { Performance }\end{array}$ & 1,145 & $\begin{array}{l}\text { Tidak } \\
\text { Signifikan }\end{array}$ & 0,116 & Positif \\
\hline $\begin{array}{l}\text { - Self-efficacy } \rightarrow \text { Employee } \\
\text { Performance }\end{array}$ & 2,690 & Signifikan & 0,491 & Positif \\
\hline $\begin{array}{l}\text { - Empowering Leadership } \rightarrow \\
\text { Self-efficacy } \rightarrow \text { Employee } \\
\text { Performance }\end{array}$ & 2,319 & Signifikan & 0,245 & Positif \\
\hline $\begin{array}{l}\text { - Perceived Organizational } \\
\text { Support } \rightarrow \text { Self-efficacy } \\
\rightarrow \text { Employee Performance }\end{array}$ & 2,091 & Signifikan & 0,180 & Positif \\
\hline $\begin{array}{l}\text { - Self-efficacy * Knowledge } \\
\text { Sharing } \rightarrow \text { Employee } \\
\text { Performance }\end{array}$ & 1,673 & Signifikan & 0,173 & Positif \\
\hline
\end{tabular}

Sumber: Data primer diolah (2019).

Hasil uji hipotesis ketiga menunjukkan bahwa nilai t-statistics pengaruh selfefficacy terhadap employee performance sebesar 2,690 (>1,64) dan nilai original sampel sebesar 0,491 (positif), sehingga H3 diterima. Artinya, ketika karyawan merasakan selfefficacy yang tinggi, maka kemampuannya itu akan meningkatkan employee performancenya. Hasil penelitian ini didukung oleh penelitian Tims et al. (2014) yang menyatakan adanya hubungan positif dan signifikan antara self-efficacy dan employee performance.

Hasil uji hipotesis keempat menunjukkan bahwa nilai t-statistics pengaruh mediasi self-efficacy terhadap empowering leadership dan employee performance sebesar 2,319 (>1,64) dan nilai original sampel sebesar 0,245 (positif), sehingga H4 diterima. Artinya, ketika karyawan mempunyai self-efficacy yang tinggi dan didukung pula oleh tingginya empowering leadership, maka kondisi tersebut akan meningkatkan employee performance. Hasil penelitian ini didukung oleh penelitian sebelumnya yang dilakukan oleh Tims et al. (2014) dan Kim dan Beehr (2017).

Hasil uji hipotesis kelima menunjukkan bahwa nilai t-statistics pengaruh mediasi self-efficacy terhadap perceived organizational support dan employee performance sebesar 2,091 (>1,64) dan nilai original sampel sebesar 0,180 (positif), sehingga H5 diterima. Artinya, ketika karyawan mempunyai self-efficacy yang tinggi dan didukung pula oleh tingginya perceived organizational support, maka hal itu akan dapat meningkatkan employee performance. Hasil penelitian ini didukung oleh penelitian sebelumnya yang dilakukan oleh Thakur dan Kumar (2015) dan Su et al. (2016). 
Hasil uji hipotesis keenam menunjukkan bahwa nilai t-statistics pengaruh moderasi knowledge sharing terhadap self-efficacy dan employee performance sebesar 1,673 $(>1,64)$ dan nilai original sampel sebesar 0,173 (positif), sehingga H6 diterima. Artinya, ketika karyawan mempunyai self-efficacy yang tinggi dan didukung pula oleh tingginya knowledge sharing, maka kondisi itu akan meningkatkan employee performance. Hasil penelitian ini didukung oleh penelitian sebelumnya yang dilakukan oleh Hsu et al. (2007) dan Kim dan Yun (2015).

\section{Pembahasan}

Penelitian ini bertujuan untuk menyelidiki pengaruh antara empowering leadership dan perceived organizational support terhadap employee performance dengan mediasi self-efficacy dan moderasi knowledge sharing pada karyawan UKM Batik HM. Sholeh di Tuban. Penelitian ini mengasumsikan dan menemukan pengaruh positif antara empowering leadership dan perceived organizational support, baik secara langsung maupun tidak langsung melalui mediasi self-efficacy dan moderasi knowledge sharing terhadap employee performance. Penelitian ini menguji enam hipotesis dasar yang menghubungkan variable-variabel dalam penelitian ini. Temuan pada penelitian ini membuktikan adanya pengaruh positif dan signifikan employee performance terhadap employee performance yang mendukung $\mathrm{H} 1$. Temuan ini sejalan dengan teori Liu et al. (2003) yang menyatakan bahwa empowering leadership adalah gaya kepemimpinan yang menargetkan pengikut untuk mengembangkan kontrol diri mereka sendiri, karyawan didorong untuk berpartisipasi dalam pengambilan keputusan, dan mereka diarahkan untuk berinovasi sendiri. Saat individu merasa bahwa dirinya diberikan kepercayaan, berpartisipasi dalam pengambilan keputusan, dan diberikan dukungan dan dorongan, maka mereka akan merasa lebih giat dalam berkinerja, sehingga employee performance dapat tercapai. Hasil empiris di lapangan juga menunjukkan bahwa besarnya empowering leadership dapat menciptakan suasana kerja yang kondusif, karena pemimpin senantiasa memberikan arahan yang bersifat membangun karakter individu, memberikan kesempatan untuk pengambilan keputusan yang partisipatif, pembinaan, serta menunjukkan kepedulian terhadap masing-masing karyawan yang tujuan utamanya untuk meningkatkan employee performance

Hasil penelitian berikutnya menunjukkan temuan yang bertentangan dengan kebanyakan penelitian sebelumnya, yaitu membuktikan adanya pengaruh positif tetapi tidak signifikan antara perceived organizational support terhadap employee performance yang menyebabkan H2 ditolak. Menurut Rhoades dan Eisenberger (2002), POS mengacu pada persepsi karyawan mengenai sejauh mana organisasi menghargai kontribusi mereka dan peduli terhadap kesejahteraan mereka. Semakin tinggi dukungan organisasi yang dirasakan karyawan, maka semakin rendah tingkat absensi mereka. Temuan ini tidak sejalan dengan penelitian sebelumnya yang dilakukan oleh Cullen et al. (2014) yang menyatakan adanya pengaruh positif dan signifikan antara perceived organizational support terhadap employee performance. Kondisi di lapangan menjelaskan bahwa organisasi yang dijadikan obyek penelitian, yaitu UKM Batik HM. Sholeh tidak memiliki aturan yang bersifat formal atau fleksibel. Pada gilirannya, sistem pemberian upah didasarkan pada kinerja yang dihasilkan oleh masing-masing karyawan, sehingga setiap karyawan akan mendapatkan upah yang berbeda sesuai dengan hasil yang mereka capai. Dari sisi lain, organisasi sangat mempertimbangkan upah yang diberikan kepada karyawan. Organisasi merasakan bahwa apabila karyawan diberikan upah atau gaji bulanan secara tetap akan sangat memberatkan organisasi, karena penda- 
patannya juga bergantung pada pesanan konsumen yang masuk setiap kali mereka memesan batik. Jumlah pesaing saat ini semakin berkembang dengan pesat, sehingga hal itu membuat omset menjadi semakin fluktuatif dan tidak menentu.

Temuan lain dari penelitian ini menunjukkan bahwa self-efficacy berpengaruh positif dan signifikan terhadap employee performance, sehingga H3 diterima. Selanjutnya, self-efficacy juga memediasi pengaruh positif dan signifikan antara empowering leadership dan employee performance. Lebih jauh, self-efficacy juga memediasi pengaruh positif antara perceived organizational support terhadap employee performance, sehingga $\mathrm{H} 4$ dan $\mathrm{H} 5$ diterima. Ketika mempelajari tugas-tugas yang kompleks, selfefficacy yang tinggi dapat menyebabkan individu berusaha untuk meningkatkan asumsi dan strategi mereka, yaitu bagaimana mereka dapat menyelesaikan tugas dengan baik dan benar. Heslin dan Klehe (2006) menyatakan bahwa self-efficacy yang tinggi dapat meningkatkan kapasitas karyawan untuk mengumpulkan informasi yag relevan, membuat keputusan yang tepat, dan mengambil tindakan yang sesuai, terutama ketika mereka berada di bawah tekanan waktu. Hasil empiris di lapangan menunjukkan bahwa peran empowering leadership dalam hal pengambilan keputusan dan otonomi serta perceived organizational support, yaitu organisasi harus berusaha dengan cermat untuk membuat karyawan merasa diperhatikan. Temuan tersebut menunjukkan makna keseluruhan mediator yaitu self-efficacy ketika kemampuan tersebut memberikan mereka rasa tanggung jawab dan kepercayaan yang tinggi dan sebagai hasilnya dapat memberikan kontribusi positif kepada organisasi.

Peran moderasi knowledge sharing memperkuat pengaruh antara self-efficacy dan employee performance, sehingga H6 diterima. Adanya knowledge sharing antarkaryawan memungkinkan organisasi untuk mengeksploitasi dan memanfaatkan sumber daya berbasis pengetahuan yang ada (Cabrera, E. \& Cabrera, A., 2005). Stasser et al. (2006) menjelaskan bahwa knowledge sharing memungkinkan anggota untuk mempertimbangkan berbagai kemungkinan untuk memecahkan masalah yang dihadapi secara efektif, yaitu menggunakan pengetahuan yang dimiliki dalam tim mereka dan membuat keputusan yang sesuai dengan konteksnya. Selain itu, knowledge sharing dapat dijadikan ajang saling berkomunikasi dengan rekan kerja untuk membantu mereka menyelesaikan sesuatu dengan lebih baik, lebih cepat, atau lebih efisien (Lin, 2007).

\section{Implikasi Penelitian}

Berdasarkan hasil penelitian dan pembahasan tersebut di atas, variabel empowering leadership, perceived organizational support, self-efficacy, knowledge sharing, dan employee performance di UKM Batik HM. Sholeh Tuban dapat ditemukan bahwa karyawan memiliki kinerja yang tinggi karena adanya dukungan, baik dari pemimpin maupun organisasi, serta rasa kepercayaan/self-efficacy yang tinggi dari karyawan yang menyebabkan kinerja menjadi lebih baik. Tingginya upaya karyawan menghasilkan kinerja yang baik tidak terlepas dari dukungan pemimpin yang senantiasa memberikan arahan, motivasi, serta menumbuhkan kepercayaan diri mereka. Hasil penelitian yang menjelaskan tingginya employee performance dapat menjadi acuan bahwa karyawan menilai organisasi mampu memenuhi kebutuhan sosial-emosional mereka dan kesiapan organisasi menghargai upaya yang telah mereka lakukan.

Hasil penelitian ini menunjukkan bahwa POS pada UKM Batik HM. Sholeh belum sepenuhnya memenuhi harapan karyawan. Jika dilihat kondisi di lapangan, hasil tersebut dapat menjelaskan bahwa organisasi UKM Batik HM. Sholeh juga tidak terma- 
suk organisasi yang bersifat bonafid, karena organisasi tersebut dapat disebut masih bertaraf home-industry. Mengingat bahwa organisasi termasuk dalam usaha skala kecil, sehingga support yang diberikan organisasi, baik yang bersifat material maupun nonmaterial kepada karyawan disesuaikan dengan kemampuan organisasi. Pelatihan tentang need analysis sangat diperlukan mengingat semakin dinamisnya pergerakan dunia bisnis terutama industri batik yang berkembang pesat, baik dari sisi pesaing maupun teknologi yang digunakan. Jadi, inovasi sangat diperlukan organisasi untuk mampu bersaing lebih kompetitif dan mampu memenuhi kebutuhan konsumen.

\section{KESIMPULAN DAN SARAN}

Penelitian ini dilakukan untuk mengetahui keterkaitan pengaruh antarvariabel pada empowering leadership, perceived organizational support, self-efficacy, knowledge sharing, dan employee performance pada UKM Batik HM. Sholeh Tuban. Hasil penelitian ini menjelaskan bahwa empowering leadership berpengaruh positif dan signifikan terhadap employee performance. Artinya, semakin tinggi empowering leaderhip dalam organisasi, maka variabel tersebut akan mempengaruhi peningkatan employee performance. Selanjutnya, perceived organizational support berpengaruh positif tetapi tidak signifikan terhadap employee performance. Artinya, meskipun karyawan merasakan adanya praktik perceived organizational support dalam organisasi, tetapi POS tidak mempengaruhi tingkat employee performance karyawan.

Self-efficacy berpengaruh positif dan signifikan terhadap employee performance. Hal itu menunjukkan bahwa ketika karyawan merasakan tingginya self-efficacy, maka hal itu akan meningkatkan pula employee performancenya. Lebih lanjut, self-efficacy juga memediasi pengaruh positif dan signifikan empowering leadership terhadap employee performance. Artinya, semakin tinggi empowering leadership yang dirasakan karyawan dan yang didukung oleh self-efficacy yang tinggi, maka kondisi tersebut akan meningkatkan employee performance. Di sisi lain, self-efficacy juga memediasi pengaruh positif dan signifikan perceived organizational support terhadap employee performance. Artinya, semakin tinggi perveived organizational support yang dirasakan oleh karyawan dan didukung oleh self-efficacy yang tinggi, maka employee performance juga akan meningkat. Knowledge sharing ditemukan memoderasi pengaruh positif dan signifikan self-efficacy terhadap employee performance. Artinya, ketika self-efficacy yang dimiliki karyawan tinggi dan diperkuat adanya knowledge sharing karyawan, maka hal itu akan meningkatkan employee performancenya.

\section{Keterbatasan Penelitian dan Arah bagi Penelitian Selanjutnya}

Penelitian ini memiliki beberapa kekurangan. Pertama, responden dalam penelitian ini sangat terbatas, yaitu 40 orang dari total populasi sebanyak 60 karyawan dengan kriteria mereka harus berprofesi sebagai pembatik. Tidak semua populasi dapat dijadikan sampel pada penelitian ini, karena ada bagian atau profesi lain, seperti pewarnaan, administrasi, penjaga toko, dan koordinator. Kedua, penelitian ini tidak membahas tentang performance appraisal dan KPI (key performance indicators) yang diterapkan organisasi-organisasi pada umumnya. Hal itu dikarenakan obyek dalam penelitian ini adalah usaha home industry yang tidak membutuhkan performance appraisal dan KPI dalam penilaian employee performance. 
Saran untuk penelitian yang akan datang adalah pertama, keterbatasan penelitian pada jumlah sampel yang digunakan tidak dapat digunakan untuk menggeneralisasi hasil pada organisasi industri batik lainnya, terutama industri batik yang berskala besar. Penelitian selanjutnya diharapkan dapat menggunakan multiobyek atau meneliti lebih dari satu industri batik. Yang kedua, penilaian dari atasan atau organisasi diperlukan untuk memperkaya hasil penelitian, terutama terkait beberapa faktor, seperti performance karyawan di pasar kerja saat ini yang tidak hanya sekedar menghasilkan output, tetapi mereka juga menghasilkan inovasi untuk keberlangsungan organisasi.

\section{DAFTAR PUSTAKA}

Ahearne, M., Mathieu, J., \& Rapp, A. (2005). To empower or not to empower your sales force? An empirical examination of the influence of leadership empowerment behavior on customer satisfaction and performance. Journal of Applied psychology, 90(5), 945.

Ahmed, I., Sultana, I., Paul, S. K., \& Azeem, A. (2013). Employee performance evaluation: A fuzzy approach. International Journal of Productivity and Performance Management, 62(7), 718-734.

Amundsen, S. \& Martinsen, O. L. (2014). Empowering leadership: Construct clarification, conceptualization, and validation of a new scale. The Leadership Quarter$l y, 25(3), 487-511$.

Anitha, J. (2014). Determinants of employee engagement and their impact on employee performance. International Journal of Productivity and Performance Management, 63(3), 308-323.

Bandura, A. (1997). Self-Efficacy: The Exercise of Control. New York: Freeman and Co.

Bandura, A. (2006). Guide for constructing self-efficacy scales. Self-efficacy Beliefs of Adolescents, 5(1), 307-337.

Byrne, Z. S. \& Hochwarter, W. A. (2008). Perceived organizational support and performance: Relationships accross levels of organizational cynicism. Journal of Managerial Psychology, 23(1), 54-72.

Cabrera, E. F. \& Cabrera, A. (2005). Fostering knowledge sharing through people management practices. The International Journal of Human Resource Management, 16(5), 720-735.

Cardy, R. L. (2004). Performance Management: Concepts, Skills and Exercises. New York: ME Sharpe, Armonk, 163.

Cavazotte, F., Moreno, V., \& Bernardo, J. (2013). Transformational leaders and work performance: The mediating roles of identification and self-efficacy. BAR-Brazilian Administration Review, 10(4), 490-512.

Chen, G., Gully, S. M., \& Eden, D (2004). General self-efficacy and self-esteem: Toward theoretical and empirical distinction between correlated self-evaluations. Journal of Organizational Behavior: The International Journal of Industrial, Occupational, and Organizational Psychology and Behavior, 25(3), 375-395.

Chen, Z., Eisenberger, R., Johnson, K. M., Sucharski, I. L., \& Aselage, J. (2009). Perceived organizational support and extra-role performance: which leads to which? The Journal of social psychology, 149(1), 119-124. 
Conger, J. A., \& Kanungo, R. N. (1988). The empowerment process: Integrating theory and practice. Academy of management review, 13(3), 471-482.

Cullen, K. L., Edwards, B. D., Casper, W. C., \& Gue, K. R. (2014). Employees' adaptability and perceptions of change-related uncertainty: Implications for perceived organizational support, job satisfaction, and performance. Journal of Business and Psychology, 29(2), 269-280.

Diliello, T. C., Houghton, J. D., \& Dawley, D. (2011). Narrowing the creativity gap: The moderating effects of perceived support for creativity. The Journal of Psychology, 145(3), 151-172.

Eisenberger, R., Huntington, R., Hutchison, S., \& Sowa, D. (1986). Perceived organizational support. Journal of Applied Psychology, 71(3), 500.

Fatima, M., Shafique, M., \& Ahmad, R. (2015). HR practices and employee performance relationship in higher education: Mediating role of job embeddedness, perceived organizational support and trust. Pakistan Journal of Statistics and Operation Research, 11(3), 421-439.

Foss, N. J., \& Pedersen, T. (2002). Transferring knowledge in MNCs: The role of sources of subsidiary knowledge and organizational context. Journal of International Management, 8(1), 49-67.

Ghozali, I. (2011). Aplikasi Analisis Multivariate dengan Program SPSS. Cetakan IV. Semarang: Badan Penerbitan Universitas Diponegoro.

Hanninen, S. (2007). Innovation commercialization process from the four knowledge bases' perspective. Helsinki University of Technology.

Heslin, P. A., \& Klehe, U. C. (2006). Self-efficacy. Encyclopedia of Industrial/ Organizational Psychology, SG Rogelberg (eds 2), 705-708.

Hori, N., Newton, R. U., Nosaka, K., \& Stone, M. H. (2005). Weightlifting exercises enhance athletic performance that requires high-load speed strength. Strength and Conditioning Journal, 24(4), 50.

Hsu, M. H., Ju, T. L., Yen, C. H., \& Chang, C. M. (2007). Knowledge sharing behavior in virtual communities: The relationship between trust, self-efficacy, and outcome expectations. International Journal of Human-computer Studies, 65(2), 153-169.

Jackson, S. E., Chuang, C. H., Harden, E. E., \& Jiang, Y. (2006). Toward developing human resource management systems for knowledge-intensive teamwork. In Research in personnel and human resources management (pp. 27-70). Emerald Group Publishing Limited.

Joo, B. K., Hahn, H. J., \& Peterson, S. L. (2015). Turnover intention: The effects of core self-evaluations, proactive personality, perceived organizational support, developmental feedback, and job complexity. Human Resource Development International, 18(2), 116-130.

Jogiyanto, H. M. (2011). Metodologi Penelitian Bisnis. Edisi Keempat. Yogyakarta: BPFE.

Kim, M., \& Beehr, T. A. (2017). Self-efficacy and psychological ownership mediate the effects of empowering leadership on both good and bad employee behaviors. Journal of Leadership \& Organizational Studies, 24(4), 466-478. 
Kim, S. L., \& Yun, S. (2015). The effect of coworker knowledge sharing on performance and its boundary conditions: An interactional perspective. Journal of Applied Psychology, 100(2), 575.

Kirkman, B. L. \& Rosen, B. (1999). Beyond self-management: Antecedents and consequences of team empowerment. Academy of Management Journal, 42(1), 58-74.

Latham, G. P., Winters, D. C., \& Locke, E. A. (1994). Cognitive and motivational effects of participation: A mediator study. Journal of Organizational Behavior, 15(1), 49-63.

Lee, E. M., Endres, S. P., Chowdhury, S. K., \& Alam, I. (2007). Tacit knowledge sharing, self-efficacy theory, and application to the open source community. Journal of knowledge management, 11(3), 92-103.

Lee, S., Cheong, M., Kim, M., \& Yun, S. (2017). Never too much? The curvilinear relationship between empowering leadership and task performance. Group \& Organization Management, 42(1), 11-38.

Liao, L. F. (2006). A learning organization perspective on knowledge-sharing behavior and firm innovation. Human Systems Management, 25(4), 227-236.

Lin, H. F. (2007). Knowledge sharing and firm innovation capability: An empirical study. International Journal of Manpower, 28(3/4), 315-332.

Liu, W., Lepak, D. P., Takeuchi, R., \& Sims Jr., H. P. (2003). Matching leadership styles with employment modes: Strategic human resource management perspective. Human Resource Management Review, 13(1), 127-152.

Mathis, R.L. \& Jackson J.H. (2000). Human Resources Management. New Jersey: Prentice-Hall, Inc.

McNeese-Smith, D. (1996). Increasing employee productivity, job satisfaction, and organizational commitment. Journal of Healthcare Management, 41(2), 160.

Mittal, S., \& Dhar, R. L. (2015). Transformational leadership and employee creativity: Mediating role of creative self-efficacy and moderating role of knowledge sharing. Management Decision, 53(5), 894-910.

Pack, S. M. (2005). Antecedents and consequences of perceived organizational support for NCAA athletic administrators. Doctoral dissertation. The Ohio State University.

Rhoades, L., \& Eisenberger, R. (2002). Perceived organizational support: A review of the literature. Journal of Applied Psychology, 87(4), 698.

Stajkovic, A. D. (2006). Development of a core confidence-higher order construct. Journal of Applied Psychology, 91(6), 1208.

Stasser, G. \& Titus, W. (2006). Pooling of unshared information in group decision making: Biased-information sampling during discussion. In Levine, H.M. \& Moreland, R.L. (Eds), Small Groups: Key Readings. New York: Psychology Press, pp. 227-239.

Su, J. M., Lee, S. C., Tsai, S. B., \& Lu, T. L. (2016). A comprehensive survey of the relationship between self-efficacy and performance for the governmental auditors. Springer Plus, 5(1), 508.

Syed-Ikhsan, O. S., \& Rowland, F. (2004). Knowledge management in a public organization: A study on the relationship between organizational elements and the 
performance of knowledge transfer. Journal of Knowledge Management, 8(2), 95111.

Thakur, A., \& Kumar, N. (2015). The effect of perceived organizational support, role related aspects and work involvement on work-life balance: Self-efficacy as a moderator. International Journal of Scientific and Research Publication, 5(1), 2250-3153.

Tims, M., Bakker, A. B., \& Derks, D. (2014). Daily job crafting and the self-efficacyperformance relationship. Journal of Managerial Psychology, 29(5), 490-507.

Tung, H. L., \& Chang, Y. H. (2011). Effects of empowering leadership on performance in management team: Mediating effects of knowledge sharing and team cohesion. Journal of Chinese Human Resources Management, 2(1), 43-60.

Yukl, G. (2006). Leadership in organizations. (6th ed.). New Jersey: Pearson-Prentice Hall, Inc. 